\title{
Nomination of Regents Election and Head Deputy with A Couple of Candidates for The of 2017 In The District Of Pati
}

\author{
Supriyanto ${ }^{1}$
}

\begin{abstract}
The enactment of Act No. 322004 is a gateway democratic progress at the local level, which mandates the direct election of regional heads, but as time goes direct elections, emerging phenomenon of elections with one candidate, reflecting the absence of competition in democracy to elect candidates for local leaders. The nomination process that provides an opportunity for citizens to come forward as a potential leader of the path of individual regions or lines of political parties are still unable to stem the phenomenon of the election by one paslon. The weakening of the political party cadres to create a cadre of local leaders, and the difficulties of citizens who want to get ahead of the path of the individual in seeking support to meet the predetermined, a major factor in the increasing phenomenon of the election by one paslon in any implementation of direct election. It also occurs in Pati Regency, Central Java province on Phase Two simultaneous elections in 2017 were only followed by one candidate, that candidate H. Haryanto, SH, MM, M.Si and H. Saiful Arifin. based onit, prompted the authors to examine the management of the Regent and Vice Regent Election of Pati with one candidate in Pati regency.

Keywords: Starch 2017 Elections, Elections One Paslon, Direct Election Phenomenon.
\end{abstract}

\section{Introduction}

Election of Regional Head and Head deputy (Election) directly by the people who in effect since 2004, experiencing a variety of demanding dynamics of the electoral system improvement. Regulation has provided space through two (2) lanes for the selection of candidates to advance in the candidacy of the elections, namely through individual lines and lines of political parties / coalitions of political parties.

The elections held since the enactment of Act No. 1 Of 2015 and its amendments, namely Act No. 8 Of 2015 and Act No. 10 In 2016, the organization of the election opportunities can be implemented with only one pair of candidates. The elections with one candidate does not embody the principles of competition or competition between candidates that normally occur in the implementation of democracy. The elections with one candidate is also a picture of a malfunction of political parties in conducting political recruitment.

In the second wave of simultaneous elections in 2017 in Central Java, there are also areas that carry out the elections with a single candidate. namely Pati regency were

\footnotetext{
${ }^{1}$ Student of Masters (S2) of Law Faculty of Law Unissula and KPU member E-mail: joebres@gmail.com
} 
only followed by one candidate, that candidate H. Haryanto, SH, MM, M.Si and H. Saiful Arifin.

Based on preliminary background description above, then the problem can be formulated as follows: 1 ) How do local elections candidacy rules so that it appears one candidate in the district of Pati? 2) How the implementation of local elections candidacy in district of Pati so that it appears one candidate?

\section{Research Methods}

The research methods used in responding to problems that arise in this thesis is as follows: This study using sociological juridical approach, the approach is based on the rule of law by examining the theories, concepts along with principles of law and rules of the law in accordance with the title of this research. Sociological juridical approach is legal research using secondary data as the first and then proceed with the primary data or data field. Examines the relationship between a variety of symptoms, or variable as a means of collecting data consists of the study of documents, observation and interview.

The research conducted in this thesis is descriptive analytical research. Analytical descriptive method is the fact finding with the proper interpretation. ${ }^{2}$ Research descriptive studying the problems in society as well as the procedure applicable in the community and specific situations, including about relationships, activities, attitudes, views, and processes the ongoing effects of a phenomenon, In the descriptive method, researchers could compare the phenomena are certain that a comparative study sometimes researchers held a clarification, as well as the study of phenomena by specifying standards or a particular norm so many experts call descriptive method is to normative survey. With descriptive methods have also investigated the position (status) phenomena or factors and see the relationship between one factor with the other factors.

\section{Results and Discussion}

\subsection{Regulation Nominations Election}

Regulation nomination phase of the elections through two ways, namely:

- The candidacy of individual lines. In the 2008 was the beginning of opening up the opportunity for citizens to step forward as candidates for Regional Head and Deputy Regional Head through the individual. Surely candidates through the individual must meet the requirements of candidates and candidacy requirements in terms of support, and in District of Pati as well as stipulated in Article 41 Paragraph (2) of Act No. 10 of 2016 candidates must have the support of advanced with the provisions at least $6.5 \%$ (six and a half percent) of the final voters list, because District of Pati has a population of more than 1.0000 .000 (one million) people, and the amount of

\footnotetext{
${ }^{2}$ FL Whitney 1960 The Elements of Resert.Asian Eds. Osaka: Overseas Book Co.
} 
support to be spread over more than $50 \%$ (fifty percent) of the sub-districts / cities is concerned, it is set out in PKPU No. 92015.

- The candidacy of political party lines. Political parties have an important role in the electoral process, Because political parties can be a representative voice of the people in the area to ask a prospective leader, desired by the people. By the rules in Article 40 Paragraph (1) of Law Number 10 Of 2016 political party can propose qualified candidates with nomination with the provisionspolitical party or coalition of political parties that obtained at least $20 \%$ (twenty percent) of the total seats in the House of Representatives or $25 \%$ (twenty five percent) of the accumulated acquisition of valid votes in the election of members of the House of Representatives in the regions concerned. As well as in Article 40 Paragraph (3) of Law Number 10 Of 2016 political party or coalition of political parties to propose candidates to use the provisions obtained at least $25 \%$ (twenty five percent) of the accumulated acquisition of valid votes as described in paragraph (1), that provision applies only to Parties that win a seat House of Representatives, which as stated in PKPU No. 9 2016. Beyond that candidates proposed by political parties must be qualified candidate has been determined.

- Rules of the nomination process with one candidate. The phenomenon of the election by one paslon began to emerge when the first phase of simultaneous election in 2015, which in some areas that are holding local elections there is only one pair of candidates who signed up to the closing period of candidate registration. It is being debated because in the Act No. 82015 set the minimum requirement of the implementation of the election to the two (2) pairs of candidates and in accordance with PKPU No. 12 in 2015, the organization of the election by only one paslon who sign up until the end of the registration period should be postponed in the elections simultaneously next stage. So some of the parties is not satisfied with these rules apply for judicial review of Act No. 8 in 2015 to the Constitutional Court, and the Court's decision was published Kosntitusi No. 100 / PUU-XIII / 2015 decided that holding the elections with a single candidate is allowed. Decision of this Court followed up by the Commission to make PKPU No. 14, 2015 in article 3 (three) includes the selection of the candidates can be implemented in terms of meeting the conditions set out as well as Article 54C of Act No. 10 of 2016 elections with one candidate can do, as well as in District of Pati election held only by one candidate because after the delay and until the expiration of the registration renewal, there is only one (1) pair of candidates who apply and based on the results of the candidates declared eligible.

\subsection{Nominations implementation in District of Pati}

Stages in the organization of the elections Pati nomination began on 11 September 2017 to 23 October 2017. Based on interviews with one Bp. Imbang Setiawan (Division Socialization Regency of Pati), "KPU Pati regency as the organizers have to socialize the nomination procedures and administrative requirements of candidates in the elections Starch 2017 which was held on 2 June 2016 and 28 July 2016, because it needs to be known by the leadership political parties, community leaders, religious leaders, the 
head of community organizations and stakeholders that the nomination can be through two (2) lanes are lanes and paths of individual political parties in accordance with PKPU No. 92015 ".

- The nomination process through individual paths

Since the announcement of the delivery of the documents requisite support would be candidates individually for 14 (fourteen) days, starting on 20 July to 2 August 2016 and until the deadline for submission of documents requisite support an individual who is scheduled from 6 to 10 August 2016, no none of the candidates who apply from individual lines. This is in contrast from the previous Pati organizing elections followed by three (3) candidates from individual lines. Weighing terms candidacy in the elections Pati 2017 requires candidates seeking the support of $6.5 \% \times 1,034,256$ (amount interchangeable) that is equal to 67227 support is a scourge that is very burdensome candidates who want to advance from individual lines.

- The process of nomination of political party lines.

\begin{tabular}{|c|l|c|}
\hline No. & \multicolumn{1}{|c|}{ Political Parties Name Bearers } & Chairs amount \\
\hline 1. & PDI Perjuangan & 8 \\
\hline 2. & Partai Gerindra & 8 \\
\hline 3. & Partai Keadilan Sejahtera & 5 \\
\hline 4. & Partai Demokrat & 6 \\
\hline 5. & Partai Golongan Karya & 6 \\
\hline 6. & Partai Hati Nurani Rakyat & 4 \\
\hline 7. & Partai Persatuan Pembangunan & 3 \\
\hline 8. & Partai Kebangkitan Bangsa & 6 \\
\hline \multicolumn{2}{r}{ Amount } & 46 \\
\hline
\end{tabular}

At the time of registration paslon on Regent and Vice Regent Election of Pati in 2017 which started on 21 to 23 September 2016, there was only one pair of candidates who apply to the Commission Pati regency on 22 September 2016 that would be candidates H. Haryanto, SH, MM , M.Si and H. Saiful Arifin carried by eight (8) Coalition of Political Parties that the PDI-P, Gerindra, PKS, the Democratic Party, Golkar, Hanura, PPP and PKB with a total of 46 seats or $92 \%$ ( ninety-two percent) of the number of seats in the local parliament Pati. ${ }^{3}$ The absence of a couple of other candidates who signed up showed courage and weakening of political parties in the political party cadre produce candidates that are ready to competent in the race for the leadership of governments in Pati. Robust incumbent also factors support some political parties for nominating a candidate for Regent and Vice Regent Pati 2017.

- Starch 2017 local elections with a single candidate.

Under the provisions of Article 89 paragraph (1) PKPU No. 9 2015, if until the end of the registration period there is only one (1) candidate, Regency Pati had to

\footnotetext{
${ }^{3}$ Pati Regency Implementation Reports Election of Regent and Vice Regent Pati year 2017 p. 102
} 
postpone the stages of the electoral, socialize these delays, and open enrollment paslon for 3 (three) days, from 29 September to 1 October 2016 . the period of delay and extension made public regarded Pati Regency just a mere formality and not substantial, because of the extended how haripun would be futile, given in the Act No. 1 of 2015 as amended by the Act No. 102016 Article 43, paragraph 1, which prohibits political party or coalition of political parties withdraw their candidates and / or their candidates resigned banned since registration as a candidate. In phase extension of the registration period is published circulars Commission No. 533 / KPU / IX / 2016 dated September 27, 2016, which allows the political party or coalition of political parties withdrew support and a new candidate, in substance contrary to the Act and PKPU, but the Commission issued a circular to accommodate the decision of the Court that the elections with one paslon do all been made earnest efforts of the ranks of the organizers to get at least two paslon or more. But until the delay and extension of registration is scheduled from 2 to 4 October in accordance with the Commission circular No. 533 / KPU / IX / 2016, there was no would be candidates to be registered at the Regency Pati.

\section{Closing}

\subsection{Conclusion}

- Implementation of Regent and Vice Regent Election of Pati in 2017 with a pair of candidates is a testament to the weakness of the party cadres to bring future leaders who can run and a strong defense capacity so that it gets the support of 8 (eight) party.

- Elections for Regent and Vice Regent Pati Of 2017 is only followed by one pair of candidates due to the limit of time to register no longer going to candidates who register.

\subsection{Suggestion}

- Terms nomination for candidates who want to get ahead of the individual lines it is still too burdensome, and should need to change the percentage of the amount of support, so that candidates can compete in the elections.

- Weak legal basis issued through circulars that are inconsistent with the Act and Regulations Election Commission.

\section{REFERENCES}

[1] F.L Whitney 1960 The Elements of Resert.Asian Eds. Osaka: Overseas Book Co.

[2] KPU Kabupaten Pati Laporan Penyelenggaraan Pemilihan Bupati dan Wakil Bupati Pati Tahun 2017

[3] Act No. 8 of 20150n the Amendment of Act No. 1 of 2015 on Stipulation of Government Regulation in Lieu of Act No. 1 of 2014 concerning the election of Governor Regent and Mayor Being the Act as the basis for the election of Governor regents and mayors directly in 2015. 
[4] Act No. 10 of 2016 on the second amendment to Act No. 1 of 2015 Concerning Determination of Government Regulation in Lieu of Act No. 1 of 2014 On the Election of Governors Regents and Mayors Become Law.

[5] Election Commission Regulation No. 9 of 2015 On Election Nomination of Governor and Deputy Governor the Regent and Vice Regent and / or the Mayor and Deputy Mayor.

[6] Election Commission Regulation No. 14 Of 2015 About the election of Governor and Vice Governor Regent and Vice Regent and / or the Mayor with One Candidate Pairs. 